\title{
Cognitive, functional and behavioral assessment Alzheimer's disease
}

\author{
Márcia L.F. Chaves ${ }^{1}$, Claudia C. Godinho ${ }^{1}$, Claudia S. Porto ${ }^{2}$, Leticia Mansur ${ }^{2,3}$, \\ Maria Teresa Carthery-Goulart ${ }^{2}$, Mônica S. Yassuda ${ }^{2,4}$, Rogério Beato ${ }^{5}$ and \\ Group Recommendations in Alzheimer's Disease and \\ Vascular Dementia of the Brazilian Academy of Neurology
}

\begin{abstract}
A review of the evidence on cognitive, functional and behavioral assessment for the diagnosis of dementia due to Alzheimer's disease $(\mathrm{AD})$ is presented with revision and broadening of the recommendations on the use of tests and batteries in Brazil for the diagnosis of dementia due to AD. A systematic review of the literature (MEDLINE, LILACS and SCIELO database) was carried out by a panel of experts. Studies on the validation and/or adaptation of tests, scales and batteries for the Brazilian population were analyzed and classified according to level of evidence. There were sufficient data to recommend the IQCODE, DAFS-R, DAD, ADL-Q and Bayer scale for the evaluation of instrumental activities of daily living, and the Katz scale for the assessment of basic activities of daily living. For the evaluation of neuropsychiatric symptoms, the Neuropsychiatric Inventory (NPI) and the CAMDEX were found to be useful, as was the Cornell scale for depression in dementia. The MiniMental State Examination has clinical utility as a screening test, as do the multifunctional batteries (CAMCOG-R, ADAS-COG, CERAD and MDRS) for brief evaluations of several cognitive domains. There was sufficient evidence to recommend the CDR scale for clinical and severity assessment of dementia. Tests for Brazilian Portuguese are recommended by cognitive domain based on available data.
\end{abstract}

Key words: consensus, guidelines, functional assessment, cognitive evaluation, behavioral assessment

\begin{abstract}
Avaliação cognitiva, comportamental e funcional: doença de Alzheimer
Resumo - Este artigo apresenta revisão e ampliação das recomendações sobre os testes e baterias empregados no Brasil para o diagnóstico e avaliação cognitiva, funcional e comportamental da demência na doença de Alzheimer (DA). De modo sistemático foi revista a literatura disponível (nas bases MEDLINE, LILACS e SCIELO) e os artigos foram avaliados e classificados por níveis de evidência, para se estabelecerem as recomendações. Para a avaliação funcional a recomendação é o uso das escalas IQCODE, DAFS-R, DAD, ADL-Q e Bayer para avaliação das atividades instrumentais da vida diária e escala Katz para avaliação das atividades básicas. Para avaliação dos sintomas neuropsiquiátricos foram recomendadas as escalas NPI e CAMDEX e a Cornell para depressão em demência. Como instrumento de rastreio deve-se utilizar o Mini-Exame do Estado Mental; quanto às baterias multifuncionais, pode-se aplicar CAMCOG-R, ADAS-COG, CERAD e MDRS, que avaliam brevemente várias funções cognitivas. Para avaliação clínica da demência e classificação de acordo com a gravidade é recomendada a escala CDR. São recomendados os testes por domínio cognitivo baseados nas evidências disponíveis para uso na nossa língua.
\end{abstract}

Palavras-chave: consenso, diretrizes, avaliação funcional, avaliação cognitiva, avaliação comportamental.

\begin{abstract}
${ }^{1}$ Neurology Service of the Hospital de Clínicas of Porto Alegre, Federal University of Rio Grande do Sul, Porto Alegre RS, Brazil; ${ }^{2}$ Cognitive and Behavioral Neurology Group of the Department of Neurology of the University of São Paulo School of Medicine, Hospital das Clínicas of the University of São Paulo School of Medicine, and Center for Mathematics, Computing and Cognition, Federal University of ABC, São Paulo SP, Brazil; ${ }^{3}$ Department of Physiotherapy, Speech Therapy and Occupational Therapy of the University of São Paulo School of Medicine, São Paulo SP, Brazil; ${ }^{4}$ Department of Gerontology, School of Arts, Sciences and Humanities of the University of São Paulo (EACH-USP East), São Paulo SP, Brazil; ${ }^{5}$ Research Group in Cognitive and Behavioral Neurology, Department of Internal Medicine, School of Medicine, Federal University of Minas Gerais (UFMG), Belo Horizonte MG, Brazil.
\end{abstract}

Márcia L.F. Chaves - Rua Ramiro Barcelos, 2350 / sala 2040 - 90035-091 Porto Alegre RS - Brazil. E-mail: mchaves@hcpa.ufrgs.br

Disclosure: The authors report no conflicts of interest.

Received March 20, 2010. Accepted in final form June 22, 2011. 


\section{Introduction}

Dementia is a prevalent condition affecting an estimated 2.4 to 4.5 million individuals in the USA, depending on the criteria adopted. ${ }^{1-3}$ Furthermore, many older adults experience memory and other cognitive function impairment. Alzheimer's disease (AD) is the most common cause of dementia, accounting for around $60 \%$ of cases of progressive cognitive impairment in the elderly population. ${ }^{4}$ Screening for $\mathrm{AD}$ before it is clinically detectable or during early stages of the disease is an extremely rational approach where interventions to prevent or delay the effects of the disease are available. However, the benefits of screening all asymptomatic elderly has neither been confirmed or refuted. ${ }^{5}$ Nonetheless, individuals reporting cognitive or cognition-related complaints should undergo comprehensive assessment. Physicians dealing with adults will encounter patients with memory impairments and should be prepared to properly assess them for causes of dementia.

Neuropsychological tests can screen for cognitive, behavioral and functional changes and assist physicians in the diagnostic process and planning of disease treatment and management strategies. As with all tests, neuropsychological assessment has its limitations and results must be interpreted set against other clinical, imaging and laboratory information. Neuropsychological assessments have the advantage of being objective, safe, portable and pertinent for measuring functional integrity of the brain. The results of neuropsychological assessments must be considered in the context of patient age, education, socioeconomic status and cultural background since these are known factors influencing performance on test batteries. In addition, technical and structural issues regarding the tests such as reliability, validity and sensitivity of assessment procedures have an impact on the conclusions reached in neuropsychological assessments. ${ }^{6}$
Neuropsychological testing is required in the diagnosis of Alzheimer's disease by a number of prevailing diagnostic criteria (NINCDS-ADRDA, DSM-IV, CID-10) and is currently one of the main means of assessing the efficacy of drugs developed for the treatment of $\mathrm{AD}$.

Physicians must perform assessments of patient mental status prior to referring them for neuropsychological tests to be carried out by trained professionals, where many clinics provide training on applying basic questionnaires. ${ }^{7-9}$ Screening tests however, produce a considerable rate of false-negative results, often failing to detect subtle cognitive changes and in many ways cannot substitute full neuropsychological testing. ${ }^{10}$

In 2006, the Scientific Department of Cognitive Neurology and Aging published recommendations for diagnosis, treatment, as well as cognitive and functional assessment. ${ }^{11}$ These recommendations are currently being updated by a panel of Brazilian experts in the field. A review of the evidence was performed by searching for relevant articles on the PUBMED, SCIELO and LILACS medical databases using key words elected for each module in order to retrieve data on national and international research. For the instruments assessed in this study, the availability of validation studies for the Brazilian population was considered an essential prerequisite given the influence of cultural and demographic aspects on performance in tests and scales. Therefore, only publications referring to Brazilian data were selected for analysis.

\section{Instrument selection}

Instruments used in cognitive, behavioral and functional assessments were selected on the databases outlined, which adopted the appropriate criteria for validation studies of tests and scales, provided they were not characterized as clinical trials. The group was therefore based on the classification given in Tables 1 and 2. ${ }^{12}$

Table 1. Classification of evidence. ${ }^{12}$

\begin{tabular}{cl}
\hline Class & Description \\
\hline I & $\begin{array}{l}\text { Evidence derived from well-planned prospective study conducted in broad spectrum of individuals with the suspected } \\
\text { condition, using "gold standard" for defining cases, where test has been applied in blinded manner and enables assessment } \\
\text { of appropriate diagnostically accurate tests. }\end{array}$ \\
II & $\begin{array}{l}\text { Evidence derived from well-planned prospective study conducted in limited spectrum of individuals with the suspected } \\
\text { condition, or by well-planned retrospective study in broad spectrum of individuals with confirmed condition (using gold } \\
\text { standard), compared with broad spectrum of control subjects, where tests have been applied in blinded manner, and enables } \\
\text { measurement of appropriate diagnostically accurate tests. }\end{array}$ \\
III $\quad \begin{array}{l}\text { Evidence derived from retrospective study in limited spectrum of individuals with the confirmed condition and control } \\
\text { subjects, in which tests have been applied in blinded manner. }\end{array}$ \\
IV $\begin{array}{l}\text { Any design methodology in which test has not been applied in blinded mode or is drawn from evidence based exclusively } \\
\text { on opinion of a specialist or on a descriptive casuistic (without controls). }\end{array}$
\end{tabular}


Table 2. Definitions for evidence-based practice recommendations. ${ }^{12}$

\begin{tabular}{ll}
\hline Recommendation & Description \\
\hline Standard & $\begin{array}{l}\text { Principle for care of patient reflecting a high degree of clinical certainty (usually requires Class I evidence directly } \\
\text { focused on the clinical issue, or indisputable evidence when circumstances preclude randomized clinical trials). }\end{array}$ \\
Norm & $\begin{array}{l}\text { Recommendation for care of patient which reflect a moderate degree of clinical certainty (usually requires Class } \\
\text { II evidence or strong consensus on Class III evidence). }\end{array}$ \\
Practice option & $\begin{array}{l}\text { Strategy for patient care of clinically uncertain use (inconclusive or evidence or conflicting opinions). } \\
\text { Suggestion }\end{array}$ \\
& $\begin{array}{l}\text { Practice recommendation for recently approved or emerging technologies or therapies and/or based on optional } \\
\text { evidence of at least one Class I study. Evidence can show some statically modest effect or clinically limited res- } \\
\text { ponse (partial), or there may be significant issues regarding cost-benefit. There may be substantial disagreement } \\
\text { (or potential) among specialists or those responsible for payment and specialists. }\end{array}$ \\
\hline
\end{tabular}

Minimum criteria included: studies with norms of age and schooling, applied in elderly and patients with dementia. Any discrepancies were explicitly stated in the event of widely used tests not fulfilling the criteria specified.

The following aspects were considered for the analysis of the instruments for the three modalities of assessment:

- Translation and adaptation.

- Internal consistency.

- Convergent and divergent validity.

- Temporal stability.

- Diagnostic validity (accuracy: sensitivity, specificity and other diagnostic parameters).

- Analysis of sociodemographic influences (age, schooling, gender).

\section{Functional assessment}

Progressive loss in the ability to perform activities of daily living (functional disability) is a primary characteristic for diagnosing dementia. Activities of daily living can be divided into basic (BADL) and instrumental (IADL). BADL are important for self-care and include the ability to carry out personal hygiene, sphincter control and feeding. IADL are more complex and include the ability to prepare meals, carry out domestic chores, manage finances and correspondence, and administer medications. ${ }^{13}$ Functional assessment is useful not only for diagnosing dementia of the Alzheimer type but also for proper guidance of patient and their caregivers and for assessing the effects of pharmacological and non-pharmacological interventions.

At the early stage of dementia due to Alzheimer's disease, a decline in IADLs is seen and functional assessment with the aim of diagnosis should focus on these aspects by using an interview with an informant or by direct assessment of the patient. Assessing BADL is relevant at more advanced stage of the disease.

Searches employing the terms "activities of daily living" and "Brazil" retrieved 406 articles from the PUBMED database, 72 from LILACS and three on SCIELO. The search terms "activities of daily living" and "Alzheimer's disease" were also used on the LILACS and SCIELO databases, identifying 23 and three articles, respectively. Studies not involving elderly were excluded as were those which investigated specific clinical conditions (e.g. patients with cardiac disease, chronic pulmonary disease, or spinal cord injuries), focused on aspects of physical mobility or profiles of physical activity, as well as studies employing semistructured interviews as opposed to scales or standardized questionnaires. The selection yielded 43 articles, among which the instruments used for assessing activities of daily living in elderly and dementia patients in Brazil were identified. In the present analysis, the most frequently used instruments in the studies were the Lawton-Brody ${ }^{14}$ for assessing instrumental activities of daily living and the Katz ${ }^{15}$ scale for assessing basic activities of daily living, Other instruments employed were the Barthel index, ${ }^{16}$ the Functional Activities Questionnaire by Pfeffer et al., ${ }^{17}$ Functional Independence Measure (FIM), ${ }^{18}$ Informant Questionnaire on Cognitive Decline in the Elderly (IQCODE), ${ }^{19}$ the Disability Assessment for Dementia (DAD), ${ }^{20}$ Bristol Activities of Daily Living Scale (BADLS), ${ }^{21}$ Bayer Activities of Daily Living Scale (B-ADL), ${ }^{22}$ Activities of Daily Living Questionnaire (ADL-Q) ${ }^{23}$ and the Direct Assessment of Functional Status-Revised (DAFS-R). ${ }^{24}$

The Katz scale and Barthel Index were used to assess BADL. The Katz scales was cross-culturally adapted for use in the Brazilian population ${ }^{25}$ (Class II) and is frequently used in studies involving patients with dementia. Similarly, the Barthel index has been validated for the Brazilian population $^{26}$ (Class II), and whose scores were found to correlate with cognitive deficit assessed by the MMSE in the elderly population. ${ }^{27}$ However, no studies were found assessing its application in AD patients. Among the instruments assessing IADL, the IQCODE, the Pfeffer scale and Lawton-Brody scale were widely used in studies on dementia patients in Brazil, ${ }^{28-31}$ but only the IQCODE had been previously validated ${ }^{28,32}$ (Class II). The Lawton scale 
had undergone a reliability study in a sample of 16 elderly without dementia (Class IV). The Pfeffer scale, despite being extensively used and cited in numerous studies, has not yet been validated.

Other instruments assessed BADL and IADL. The DAD $^{20,34,35}$ (Class III and II studies, respectively), Bayer ${ }^{22,36,37}$ (Class II) and DAFS-R ${ }^{24,38}$ (Class II) scales have corresponding validation studies and rates of diagnostic accuracy for dementia due to AD. The ADL-Q scale had been translated, adapted and analysed for psychometric characteristics ${ }^{23,39}$ (Class II), but had no associated studies in Brazil assessing its diagnostic accuracy for AD. The MIF was validated in Brazil for patients with spinal cord injury ${ }^{18,40}$ (Class II) and was used in studies on elderly groups. ${ }^{41}$ However, only one study analyzing its application in $\mathrm{AD}$ patients was identified. ${ }^{42}$ The BADL was used in studies of dementia patients $s^{43,44}$ but no studies on its adaptation or validation for use in the Brazilian population were available.

Recommendations - For the diagnosis of $\mathrm{AD}$, the use of the IQCODE, DAFS-R, DAD, ADL-Q and Bayer scales can be recommended to assess IADL given they have Class II and III studies validating their use (norm). The Katz scale may be used for assessing BADL in AD patients (norm).

Note - It is current practice in our setting to use scales for which there are no validation studies held on the data bases searched, such as the Pfeffer scale ${ }^{17}$ and the BADLS, ${ }^{21}$ pointing to the need for future studies.

\section{Behavioral assessment}

Behavioral and psychological symptoms of Alzheimer's disease are common during the course of disease evolution, being one of the main reasons for institutionalization, use of medications, high costs of care and family burden.

Several instruments have been developed to systematically assess the neuropsychiatric symptoms of AD. The majority of these scales consist of symptoms rated by informants, typically patient family members and/or caregivers.

Descriptors used:

- Neuropsychiatric Symptoms and dementia or AD.

- Behavioral symptoms and dementia or AD.

- Neuropsychology and dementia or AD.

- Behavioral problems and dementia or AD.

- Behavioral and psychological symptoms (BPSD) and dementia or AD.

According to the review carried out for the search terms above, the most used scales internationally were: Neuropsychiatric Inventory - NPI ${ }^{45}$ Behavior Rating Scale for Dementia of the Consortium to Establish a Registry for Alzheimer's Disease (CERAD-BRSD) ${ }^{46}$ Behavioral Pathol- ogy in Alzheimer's Disease Scale (BEHAVE-AD), ${ }^{47}$ and section A of the CAMDEX-R (Cambridge Examination for Mental Disorders of the Elderly - Revised Version). ${ }^{48}$ The Cornell Scale for Depression in Dementia ${ }^{49}$ and the Dementia Mood Assessment Scale (DMAS) ${ }^{50}$ were found for the assessment of depressive symptoms. Cohen-Mansfield Agitation Inventory (CMAI) ${ }^{51}$ is widely used for assessing the broad spectrum of agitation symptoms.

On a national level, 22 articles were found using the same key words, with only 3 articles addressing instrument adaptation and/or validation. Adaptation and/or validation studies were found for the NPI scale, ${ }^{52}$ section A of the CAMDEX-R scale ${ }^{53}$ (Class II), and Cornel1 ${ }^{54}$ (Class III) scale that fulfilled the minimum criteria for validation.

\section{Recommendations - The NPI and CAMDEX scales} (Class II or III studies) can be used for the assessment of neuropsychiatric symptoms in AD patients (norm). The Cornell scale can be employed for evaluating depressing symptoms (Class IV)(practice option).

\section{Brief cognitive screening instruments}

Brief screening Instruments not requiring extensive training and that can be applied by a range of health professionals tend to be used in primary care services The descriptors used to search for evidence were: mental status and dementia or $\mathrm{AD}$ and Brazil, screening test and dementia or $\mathrm{AD}$ and Brazil.

The descriptors applied in the search were mental state AND screening AND dementia AND Brazil. Of all the articles retrieved from the databases on brief instruments $(\mathrm{n}=87)$ applied in Brazil, 29 involved adaptation and/or validation stages of some kind.

The Mini-Mental State Exam (MMSE) was the most used instrument for this purpose and has normative data, testretest reliability, and diagnostic accuracy as described below.

The MMSE was designed to be an assessment of change in cognitive status of geriatric patients for application in routine clinical practice. ${ }^{7}$ It examines time and spatial orientation, short-term memory (immediate or attention) and recall, calculus, praxia, language and visuospatial skills. The MMSE can be used as a screening test for cognitive loss or as a bedside cognitive instrument.

Another brief test is the Cognitive Abilities Screening Instrument-Short Form: CASI-S) ${ }^{67}$ a scale with a validations study in Brasil. ${ }^{68}$ Some batteries incorporate a section on cognitive assessment without taking much longer to apply, such as the Brief Cognitive Screening Battery (BCSB) and Addenbrooke's Cognitive Examination-Revised (ACE$\mathrm{R})^{69}$ which also has associated validation studies for the Brazilian population. ${ }^{70-73}$ 
Table 3. Sensitivity and Specificity of Mini Mental State Exam for detecting dementia.

\begin{tabular}{ll}
\hline Study & Sample \\
\hline $\begin{array}{l}\text { Chaves and Izquierdo, } \\
1992^{55}\end{array}$ & $\begin{array}{l}31 \text { patients with dementia, } 31 \text { patients with } \\
\text { major depression and } 22 \text { healthy controls }\end{array}$ \\
$\begin{array}{l}\text { Bertolucci et al., } \\
1994^{56}\end{array}$ & $\begin{array}{l}\text { 94 patients with cognitive impairment and } \\
\text { Almeida, }\end{array}$ \\
$\begin{array}{l}\text { 1998 } 5^{57} \\
\text { Caramelli et al., }\end{array}$ & $\begin{array}{l}\text { Population-based sample, } 1656 \text { elderly } \\
1999^{58}\end{array}$ \\
& $>64$ ys, 570 illiterates, 188 with dementia - \\
& $10^{\text {th }}, 25^{\text {th }}$ and $50^{\text {th }}$ percentiles defined
\end{tabular}

Bertolucci et al., $2001^{59}$

Brucki et al., $2003^{60}$

Laks et al., $2003^{61}$

Lourenço and Veras, $2006^{62}$

Laks et al., $2007^{63}$

Castro-Costa et al., $2008^{64}$

Lourenço et al., $2008^{65}$

Kochhann et al., $2010^{66}$
85 healthy elderly and 43 patients with $\mathrm{AD}$

433 normal individuals

341 elderly

303 elderly general outpatients 78 with dementia by DSM-IV

870 elderly from community

1558 individuals ( $\geq 60 \mathrm{ys}$ ) from community

306 individuals $\geq 65$ ys, outpatients

105 sub-sample of 1 week retest

162 patients with dementia 806 healthy elderly

\section{Cut-off}

24

Sensitivity

Specificity

$96 \%$ $68 \%$

Illiterates: 13

$82.4 \%$

$97.5 \%$

Schooling $<8$ years: 18

$75.6 \%$

$96.6 \%$

Schooling $\geq 8$ years: 26

$80 \%$

$95.6 \%$

Illiterates: 19

$80 \%$

$71 \%$

Schooled: 23

$84 \%$

$60 \%$

Illiterates: 15, 18, 20

Schooling:

1-3 years: $21,23,25$

4-7 years: $22,25,26$

$>7$ years: $25,26,28$

$$
26
$$

$97.6 \%$

$75.3 \%$

Illiterates: 20

By schooling

1-4 years: 25

5-8 years: 26.5

9-11: 28

>11: 29

Younger old: 19.9

Older old: 16.9

Illiterates: 17.1

Schooled: 22.3

Illiterates: 18/19

Schooled: 24/25

$\begin{array}{cc}73.5 \% & 73.9 \% \\ 75 \% & 69.7 \%\end{array}$

Younger old

Illiterates: 19.5

1-8 years: 23.9

Older old

Least schooled: 18.1

Most schooled: 23.8

\section{General}

$5^{\text {th }}$ Percentile: 14

95 ${ }^{\text {th }}$ Percentile: 22

60-64 years:

$5^{\text {th }}$ Percentile: 17

95 ${ }^{\text {th }}$ Percentile: 24

$\geq 65$ years:

$5^{\text {th }}$ Percentile: 13

95 ${ }^{\text {th }}$ Percentile: 16

PC: 23/24

Illiterates: 21

Low schooling: 22

Medium: 23

High: 24
$69.7 \%$ 
Recommendations - The Mini-Mental State Exam can be used for the assessment of mental status/cognitive screening in the detection of $\mathrm{AD}$ (standard). Other instruments such as the CASI-S, the Brief Cognitive Screening Battery and the Addenbrooke's Cognitive Examination-Revised can also be used, broadening the scope of cognitive assessment (norm).

\section{Multi-functional batteries}

Multifunctional batteries provide more in-depth assessment but need longer to apply and a specific setting for application.

The search terms neuropsychological tests/neuropsychological battery AND dementia AND validity/applicability/ adaptation/sensitivity AND Brazil were employed to assess the situation of multifunctional batteries. Of all the articles retrieved from the databases $(n=83)$ only 12 assessed aspects of adaptation, reliability or accuracy of specific batteries. The Cambridge Cognitive Examination-Revised: CAMCOG-R), ${ }^{48}$ Alzheimer's Disease Assessment Scale-cognitive sub-scale: ADAS-COG) ${ }^{74}$ Consortium to Establish a Registry for Alzheimer's Disease: CERAD), ${ }^{9}$ Mattis Dementia Rating Scale: MDRS ${ }^{75}$ has corresponding adaptation, reliability or validation studies in Brazil ${ }^{59,76,77}$ (Class II and III).

Recommendations - The CAMCOG-R, ADAS-COG, CERAD and MDRS scales are valid for use in the assessment of multifunctional neuropsychology in Alzheimer's disease (pattern).

\section{Specific cognitive areas}

The selection of the evidence was performed using the PUBMED database with the terms "memory", "dementia", "Brazil", with the limits "Humans", "English", Spanish"',65+ years'," $80+$ years" retrieved 58 articles, of which 15 were related to cognitive instruments. Using the same constraints, another search was carried out with the key words "memory", "elderly" "Brazil" that yielded 131 articles. This search identified 15 articles that had been previously matched, and seven newly found articles on cognitive instruments. The same procedure was repeated, replacing the word "memory" with "attention" and returned 12 articles, all of which either matched those found on previous searches or were not relevant to the theme of cognitive instruments. The search procedure was repeated using the words "executive function" and subsequently with "visuospatial", finding 12 and 5 articles, respectively. Three new articles on cognitive instruments were identified - two of which were on executive functions and one on visuospatial functions. In total, 25 Brazilian articles were identified addressing the assessment of cognitive instruments used in the Brazilian elderly population.

On the LILACS database, the search words "memory" and "dementia" were used, identifying a total of 315 matches, 10 of which had previously been located on PUBMED. The search was repeated with "attention test" and "dementia" yielding 24 articles, four of which were new relevant articles.

Using the words "executive function" and "dementia", seven articles were identified. However, all had previously

Table 4. Summary of results of databases searches for memory function assessment.

\begin{tabular}{|c|c|c|c|}
\hline \multirow[b]{2}{*}{ Database } & \multirow[b]{2}{*}{ Terms used } & \multicolumn{2}{|c|}{ No. of articles } \\
\hline & & Retrieved & Selected \\
\hline \multirow[t]{5}{*}{ PUBMED } & Memory $\times$ Dementia $\times$ Brazil & 58 & 15 \\
\hline & Memory $\times$ Elderly $\times$ Brazil & 131 & 7 \\
\hline & Attention $\times$ Dementia $\times$ Brazil & 12 & 0 \\
\hline & Executive function $\times$ Dementia $\times$ Brazil & 12 & 2 \\
\hline & Visuospatial $\times$ Dementia $\times$ Brazil & 5 & 1 \\
\hline \multirow[t]{4}{*}{ LILACS } & Memory $\times$ Dementia & 315 & 10 \\
\hline & Attention test $\times$ Dementia & 24 & 4 \\
\hline & Executive function $\times$ Dementia & 8 & 0 \\
\hline & Visuospatial $\times$ Dementia & 2 & 0 \\
\hline \multirow[t]{5}{*}{ SCIELO } & Memory $\times$ Dementia & 57 & 2 \\
\hline & Memory $\times$ Elderly & 33 & 2 \\
\hline & Attention test $\times$ Dementia (or elderly) & 0 & 0 \\
\hline & Executive function $\times$ Dementia (or elderly) & 0 & 0 \\
\hline & Visuospatial $\times$ Dementia (or elderly) & 0 & 0 \\
\hline
\end{tabular}


been retrieved in earlier searches or were not pertinent to the theme. Using the search terms "visuospatial" and "dementia", two articles were located, which again were not relevant or had been located in earlier searches. The searches were repeated by cross referencing each cognitive function with the word "elder", returning nine hitherto unidentified articles.

The same search strategies used on LILACS were repeated for the SCIELO database. A search using "memory" and "dementia" produced 57 articles, whereas "memory" and "elderly" found 33 papers, four of which were new. The searches with the words "attention test", executive function", "visuospatial" cross-referenced with "dementia" or "elderly" produced no matches. Table 4 summarizes the results of the searches carried out on the databases.

The analysis of articles selected and discussion among panel members led to a consensus on the scientific evidence supporting the use of the previously studied cognitive instruments in Brazil. The resultant recommendations for clinical use are outlined below under each specific cognitive area.

\section{Memory}

Memory problems are the most important component in cognitive investigation for inclusion in the diagnostic criteria of AD. Patients with AD manifest early deficits in the acquisition of new information and loss of information during later recall. The tests recommended for assessing memory include immediate and delayed recall of words, and concrete or abstract figures in verbal and visual modalities.

For assessing verbal memory, the Rey Auditory Verbal Learning Test ${ }^{78-83}$ (RAVLT) and the word list from the cognitive battery of the Consortium to Establish a Registry for Alzheimer's Disease (CERAD) $)^{59,84,85}$ are tests which meet the minimum validation requirements having significant normative data and wide application in the Brazilian population.

For assessing visual memory, the 10 figure test from the Brief Cognitive Screening Battery (BCSB) ${ }^{71,86-90}$ and the geometric figure recall task from the CERAD battery, ${ }^{59,84,85}$ are tests which meet the minimum validation requirements, having significant normative data and wide application in the Brazilian population.

Rey's Complex Figure Test assesses both visuoconstruction and non-verbal memory. The validation for the Brazilian elderly population was recently constructed, broadening the potential scope of applications underway in our milieu. $^{91,92}$

The Rivermead Behavioural Memory Test (RBMT), ${ }^{93,94}$ the Short Cognitive Performance Test (SKT) ${ }^{95,96}$ and the Logical Memory subtest of the Wechsler Memory Scale - III (WMS-III) ${ }^{55,97}$ were preliminarily validated for the Brazil- ian population through the growing number of applications of the test in the country.

Recommendations - The RAVLT tests, ten figures from the BCSB, and the word list and figure recall of the CERAD battery should be used for assessing memory in the diagnosis of AD - Class II and III studies (guideline). Rey's Complex Figure should be used while considering its limitations in clinical value (practice option). Notes - Although widely applied in the Brazilian population, the Figure Object Memory Evaluation (FOME) ${ }^{94,97}$ the Selective Reminding Test and the Visual Reproduction test of the WMS-III battery still lack validation studies for Brazil.

\section{Attention}

Attention can be compromised in early phases of AD. Patients with $\mathrm{AD}$ experience deficits in all types of attention, with greatest difficulty in switching attentional focus.

In the auditory modality, the recommended tests include the forward (attentional abilities) and backward (executive and attentional control abilities) digit span test from the Wechsler Adult Intelligence Scale III (WAIS-III) test battery. The WAIS-III has been translated and adapted to Portuguese and the norms for the Brazilian population are available and extensively used. ${ }^{98,99}$

In the visual modality, the Trail Making test included two modalities - part A recruits attention and part B divided attention. Many Brazilian studies involve the use of the Trail Making test. Although not validated for use in Brazil, some studies report comparisons among clinical groups and norms for age groups organized by level of schooling. ${ }^{91,94,100,101}$

Recommendations - The forward/backward Digit Span subtest should be used to assess attention in $\mathrm{AD}$ diagnosis (norm).

\section{Executive functions}

Deficit in executive functions - election of objectives, planning, organizing responses and monitoring encompass the group of alterations seen in AD. The Clock Drawing Test (CDT) is able to assess multiple cognitive domains including semantic memory, visuoconstruction and executive functions, given that good performance requires planning and monitoring of actions. The CDT is validated for use in Brazil and has an established cut-off score for AD applicable to the Brazilian population. ${ }^{102-108}$

The Wisconsin Card Sorting Test is considered the classic instrument for assessing executive functions, since it measures understanding of rules for card combinations 
and the ability to change the rules during the course of the task. The test has defined norms for the elderly Brazilian population (application manual), although no validation studies were available in the databases consulted. Studies using the test in the Brazilian elderly were found ${ }^{91,109}$ while another study suggested the method of application, albeit manual or computer-based, had no influence on outcomes among elderly Brazilians. ${ }^{110}$

The executive aspect is prominent in the verbal fluency tests. In Brazil, normative data are available for phonemic fluency - age group, age and schooling ${ }^{111,112}$ and for semantic fluency - age group and schooling ${ }^{113-116}$ and from applications of these instruments in clinical studies.

Also with regard to executive function, the Similarities subtest of the WAIS-III battery for assessing abstract thought was validated with norms established for the Brazilian aged population. The Stroop test, although frequently used in our milieu, has not yet been formally validated for the Brazilian population..$^{91,109}$

Recommendations - The CDT and verbal fluency tests (phonemic and semantic) can be used for assessing executive functions in AD (guidelines). The Similarities subtest of the WAIS-III battery can be used for assessing abstraction ability (practice option).

Notes - The Executive Interview EXIT-25, ${ }^{117,118}$ Battery for Behavioral Assessment of the dysexecutive Syndrome (BADS) ${ }^{19,120}$ and the Frontal Assessment Battery $(\mathrm{FAB})^{121}$ are currently undergoing the initial stage of validation in Brazil.

\section{Visuoperceptual and constructive abilities}

These abilities are impaired in the late stages of $\mathrm{AD}$ and no tests have been fully validated in Brazil for assessing these cognitive aspects. For assessing visuoconstructive abilities, the Figure Copying subtest of the CERAD battery has preliminary validation. ${ }^{59,84,85}$ The CDT cited above is also used to assess visuoconstructive ability. ${ }^{102-106,108}$ The Cubes subtest of the WAIS-III battery can also be used since it has been validated for Brazil. ${ }^{97-99}$ Rey's Complex Figure which, although the focus of few studies in the Brazilian elderly population, ${ }^{91,92}$ may be utilized to assess planning ability during the execution of a visuoconstructive task.

Another option for assessing visuoperceptual ability is the Matrix Reasoning subtest of the WAIS-III battery, validated for use in Brazil, ${ }^{97-99}$ a test which is equivalent to the Raven's Colored Progressive Matrices test. This latter test has been validated for use in children and may also be employed in the assessment of elderly. However, no studies on this instrument were found on the databases searched.

Recommendations - The Figure copying and CDT tests should be used for assessing constructive abilities in $\mathrm{AD}$ (norm).

\section{SUGGESTED MINIMUM PROTOCOL}

A proposed minimum protocol for assessing specific cognitive functions in dementia of the Alzheimer type is given in Table 5.

Table 5. Minimum protocol proposed by Consensus for assessing specific cognitive areas for diagnosis of dementia of the Alzheimer type.

\begin{tabular}{lll}
\hline Cognitive domains & $\begin{array}{l}\text { Brief assessment } \\
(\mathbf{3 0} \text { minutes or less) }\end{array}$ & $\begin{array}{l}\text { Expanded assessment } \\
\text { (approx. 1 hour) }\end{array}$ \\
\hline Memory & $\begin{array}{l}10 \text { figures from BCSB } \\
10 \text { words from CERAD }\end{array}$ & $\begin{array}{l}\text { RAVLT } \\
\text { Logical Memory (WMS-III) } \\
\text { CERAD Figure Recall } \\
\text { Rey's Complex Figure }\end{array}$ \\
Attention and Executive functions & & Similarities (WAIS-III) \\
& Forward and Backward Digit Span & FAS \\
& Verbal Fluency Animals & Wisconsin Card Sorting Test \\
& CDT & Trail-making A and B \\
Language & & Boston Battery \\
& Boston Naming & Arizona Battery \\
Visuoperceptual and visuoconstruction & CDT & Reasoning Matrix (WAIS-III) \\
& & Figure Copying from CERAD \\
& & Rey's Complex Figure \\
\hline
\end{tabular}




\section{Language}

Language difficulties are acknowledged as an early sign of $\mathrm{AD}$, particularly naming difficulties.

In relation to language, the database searches used the terms language $\times$ Alzheimer's disease, and found no published articles on the topic. The closest terms were language and cognition which identified 3 (three) publications none of which were relevant for the theme in question. Similarly, a search for "language $\times$ Alzheimer's disease" on LILACS found no published articles. The closest uniterms on the theme of interest were language and cognition. A total of 92 articles were found on PUBMED, two of which were Brazilian publications pertinent to the theme.

On PUBMED, studies were identified on Boston Naming, ${ }^{122}$ undoubtedly the most commonly used test for this purpose. In Brazil, there is an adaptation and norms study for different age and schooling groups involving a large sample, with suggested expected performance values for different age groups, genders and educational levels. ${ }^{123}$ The verbal fluency tests are also used with the aim of detecting lexical compromise in early AD. Studies in Brazilian Portuguese sought to determine the effects of age, schooling and gender on semantic verbal fluency. ${ }^{113,116}$

The Arizona battery is recommended for assessing the language/memory interface in dementia and has been the subject of preliminary validation and accuracy studies The full protocol of the Boston battery has a similar validation status. ${ }^{124,125}$ Other comprehensive batteries for assessing language were applied in samples of healthy individuals, enabling the determination of performance cut-off scores. This is also the case for the Beta-MT Battery. ${ }^{126}$ All of the cited studies are Class III level of evidence.

Recommendations - The assessment of language for diagnosing $\mathrm{AD}$ should be carried out using the Boston Naming or semantic verbal fluency test (guidelines). Patients showing impairment on the recommended tests should undergo more rigorous assessment by the Arizona, Boston or Beta MT batteries (practice option).

\section{Clinical dementia rating scale}

The clinical dementia rating scale $-\mathrm{CDR}^{127}$ has associated Class I and II validation studies in Brazil. ${ }^{128-130}$

Recommendations - In order to assess dementia in Alzheimer's disease, as well as classify patients according to disease stage, the clinical dementia rating (CDR) can be used (standard).

\section{Final comments}

In view of the profile of the instruments in use for cognitive, functional and behavioral evaluations and also the validation studies which cover the majority of the psychometric characteristics of many tests and scales, it can be recommended that further studies of this nature be fostered in Brazil and run with the support of research funding bodies.

It should be stressed that the analyses and recommendations outlined apply specifically to the diagnosis of Alzheimer's disease. Mild cognitive impairment (MCI), in its broader meaning or in reference to the more specific precursor to Alzheimer's disease (according to diagnostic guidelines) warrants a separate review to determine the value of the tests and scales available for cognitive, functional and behavioral assessment. The challenge of reaching a consensus for the diagnosis of $\mathrm{MCI}$ remains.

\section{References}

1. Hebert LE, Scherr PA, Bienias JL, Bennett DA, Evans DA. Alzheimer disease in the US population: prevalence estimates using the 2000 census. Arch Neurol 2003;60:1119-1122.

2. Lobo A, Launer LJ, Fratiglioni L, et al. Prevalence of dementia and major subtypes in Europe: a collaborative study of population-based cohorts. Neurologic Diseases in the Elderly Research Group. Neurology 2000;54(11 Suppl 5):S4-S9.

3. Hy LX, Keller DM. Prevalence of AD among whites: a summary by levels of severity. Neurology 2000;55:198-204.

4. Cummings JL, Cole G. Alzheimer disease. JAMA 2002; 287:2335-2338.

5. Boustani M, Peterson B, Hanson L, Harris R, Lohr KN. Screening for dementia in primary care: a summary of the evidence for the US Preventive Services Task Force. Ann Intern Med 2003;138:927-937.

6. Levin HS. A guide to clinical neuropsychological testing. Arch Neurol 1994;51:854-859.

7. Folstein MF, Folstein SE, McHugh P. The "Mini-Mental State": a practical method of grading the cognitive state of patients for the clinician. J Psychiatr Res 1975;12:189-198.

8. Kiernan RJ, Mueller J, Langston JW, Van Dyke C. The Neurobehavioral Cognitive Status Examination: a brief but quantitative approach to cognitive assessment. Ann Intern Med 1987;107:481-485.

9. Morris JC, Heyman A, Mohs RC, et al. The Consortium to Establish a Registry for Alzheimer's Disease (CERAD). Part I. Clinical and neuropsychological assessment of Alzheimer's disease. Neurology 1989;39:1159-1165.

10. Nelson A, Fogel BS, Faust D. Bedside cognitive screening instruments: a critical assessment. J Nerv Ment Dis 1986; 174:73-83.

11. Nitrini R, Caramelli P, Bottino CM, Damasceno BP, Brucki SM, Anghinah R; Academia Brasileira de Neurologia. [Diagnosis of Alzheimer's disease in Brazil: cognitive and 
functional evaluation. Recommendations of the Scientific Department of Cognitive Neurology and Aging of the Brazilian Academy of Neurology]. Arq Neuropsiquiatr 2005; 63:720-727.

12. Knopman DS, DeKosky ST, Cummings JL, et al. Practice parameter: diagnosis of dementia (an evidence-based review). Report of the Quality Standards Subcommittee of the American Academy of Neurology. Neurology 2001;56:1143-1153.

13. Gauthier S, Gelinas I, Gauthier L. Functional disability in Alzheimer's disease. Int Psychogeriatr 1997;9 Suppl 1: 163-165.

14. Lawton MP, Brody EM. Assessment of older people: selfmaintaining and instrumental activities of daily living. Gerontologist 1969;9:179-186.

15. Katz S, Ford AB, Moskowitz RW, Jackson BA, Jaffe MW. Studies of illness in the aged. The index of ADL: a standardized measure of biological and psychosocial function. JAMA 1963;185:914-919.

16. Mahoney FI, Barthel D. "Functional evaluation: the Barthel Index”. Maryland State Medical Journal 1965;14:56-61.

17. Pfeffer RI, Kusosaki TT, Harrah Jr CH, Chance JM, Filos S. Measurement of functional activities in older adults in the community. J Gerontol 1982;37:323-329.

18. Keith RA, Granger CV, Hamilton BB, Sherwin FS. The functional independence measure: a new tool for rehabilitation. Adv Clin Rehabil 1987;1:6-18.

19. Jorm AF, Jacomb PA. The Informant Questionnaire on Cognitive Decline in the Elderly (IQCODE): socio-demographic correlates, reliability, validity and some norms. Psychol Med. 1989;19:1015-1022.

20. Gauthier L, Gelinas I, Mcintyre M, Gauthier S, Laberge H, Dauphinee SW. Disability Assessment for Dementia (DAD) user's guide; 1994.

21. Bucks RS, Ashworth DL, Wilcock GK, Siegfried K. Assessment of activities of daily living in dementia: development of the Bristol Activities of Daily Living Scale. Age Ageing 1996;25:113-120.

22. Hindmarch I, Lehfeld H, de Jongh P, Erzigkeit H. The Bayer Activities of Daily Living Scale (B-ADL). Dement Geriatr Cogn Disord 1998;9 Suppl 2:20-26.

23. Johnson N, Barion A, Rademaker A, Rehkemper G, Weintraub S. The Activities of Daily Living Questionnaire: a validation study in patients with dementia. Alzheimer Dis Assoc Disord 2004;18:223-230.

24. Loewnstein DA \& Bates CB. The Direct Assessment of Functional Status-Revised (DAFS-R). Manual for administration and scoring. Neuropsychological Laboratories and the Wien Center for Alzheimer's Disease and Memory Disorders, Mount Sinai Medical Center; 2006.

25. Lino VTS, Pereira SRM, Camacho LAB, Ribeiro Filho ST, Buksman S. Adaptação transcultural da Escala de Independência em Atividades da Vida Diária (Escala de Katz). Cad Saude Publica 2008;24:103-112.

26. Minosso JSM, Amendola F, Alvarenga MRM, Oliveira MAC. Validação, no Brasil, do Índice de Barthel em idosos atendidos em ambulatórios. Acta Paul Enferm 2010;23:218-223.
27. Converso MER, Iartelli I. Caracterização e análise do estado mental e funcional de idosos institucionalizados em instituições públicas de longa permanência. J Bras Psiquiatr 2007;56:267-272.

28. Bustamante SEZ, Bottino CMC, Lopes MA, et al. Instrumentos combinados na avaliação de demência de idosos. Arq Neuropsiquiatr 2003;61:601-606.

29. Laks J, Batista EM, Guilherme ER, et al. Prevalence of cognitive and functional impairment in community-dwelling elderly: importance of evaluating activities of daily living. Arq Neuropsiquiatr 2005;63:207-212.

30. Marra TA, Pereira LSM, Faria CDCM, Pereira DS, Martins MAA, Tirado MGA. Avaliação das atividades de vida diária de idosos com diferentes níveis de demência. Rev Bras Fisioter 2007;11:267-273.

31. Laks J, Baptista EMR, Contino ALB, de Paula EO, Engelhardt E. Mini-Mental State Examination norms in a community-dwelling sample of elderly with low schooling in Brazil. Cad Saude Publica 2007;23:315-319.

32. Sanchez MA, Lourenço RA. Informant Questionnaire on Cognitive Decline in the Elderly (IQCODE): cross-cultural adaptation for use in Brazil. Cad Saude Publica 2009; 25:1455-1465.

33. Santos RL, Virtuoso Jr JS. Confiabilidade da versão brasileira da escala de atividades instrumentais da vida diária. RBPS 2008;21:290-296.

34. Carthery-Goulart MT, Areza-Fegyveres R, Schultz RS, et al. Adaptação transcultural da Escala de Avaliação de Incapacidade de Demência (Disability Assessment For Dementia - DAD). Arq Neuropsiquiatr 2007;65:916-919.

35. Bahia VS, Carthery-Goulart MT, Novelli MM, et al. Functional disability in Alzheimer disease: a validation study of the Brazilian version of Disability Assessment for Dementia (DAD-Br). Alzheimer Dis Assoc Disord 2010;24:291-295.

36. Mapi Research Institute. Cultural Adaptation of the Bayer Activities of Daily Living Scale (B-ADL) into Brazilian Portuguese. Report. Lyon-France: Mapi Research Institute; 1999:1-19.

37. Folquito JC, Bustamante SEZ, Barros SB, et al. The BayerActivities of Daily Living Scale (B-ADL))in the differentiation between mild to moderate dementia and normal aging. Rev Bras Psiquiatr 2007;29:350-353.

38. Pereira FS, Oliveira AM, Diniz BS, Forlenza OV, Yassuda MS. Cross-cultural adaptation, reliability and validity of the DAFS-R in a sample of Brazilian older adults. Arch Clin Neuropsychol 2010;25:335-343.

39. Medeiros ME, Guerra RO. Tradução, adaptação cultural e análise das propriedades psicométricas do Activities of Daily Living Questionnaire (ADLQ) para avaliação funcional de pacientes com a doença de Alzheimer. Rev Bras Fisioter 2009;13:257-266.

40. Riberto M, Miyazaki MH, Jucá SSH, Sakamoto H, Pinto PPN, Battistella LR. Validação da Versão Brasileira da Medida de Independência Funcional. Acta Fisiatr 2004;11:72-76.

41. Rosset I, Roriz-Cruz M, Santos JL, Haas VJ, Fabrício-Wehbe SC, Rodrigues RA. Socioeconomic and health differen- 
tials between two community-dwelling oldest-old groups. Rev Saude Publica 2011;45:391-400.

42. Talmelli LFS, Gratao ACM, Kusumota L, Rodrigues, RAP. Nível de independência funcional e déficit cognitivo em idosos com doença de Alzheimer. Rev Esc Enferm 2010,44: 933-939.

43. Wajman JR, Bertolucci PHF. Comparison between neuropsychological evaluation instruments for severe dementia. Arq Neuropsiquiatr 2006;64:736-740.

44. Nazir E, Mushtaq M. A prospective study on the use of rivastigmine transdermal patch in Alzheimers dementia in a routine clinical setting. Dement Neuropsychol 2010;4: 245-249.

45. Cummings JL, Mega M, Gray K, Rosenberg-Thompson S, Carusi DA, Gornbein J. The Neuropsychiatric Inventory: comprehensive assessment of psychopathology in dementia. Neurology 1994;44:2308-2314.

46. Tariot PN, Mack JL, Patterson MB, et al. The Behavior Rating Scale for Dementia of the Consortium to Establish a Registry for Alzheimer's Disease. The Behavioral Pathology Committee of the Consortium to Establish a Registry for Alzheimer's Disease. Am J Psychiatry 1995;152:1349-1357.

47. Reisberg B, Borenstein J, Salob SP, Ferris SH, Franssen E, Georgotas A. Behavioral symptoms in Alzheimer's disease: phenomenology and treatment. J Clin Psychiatry 1987;48 Suppl:9-15.

48. Roth M, Huppert F, Mountjou CQ, Tym E. CAMDEX-R: The Cambridge Examination for Mental Disorders of the Elderly. Cambridge: Cambridge University Press; 1998.

49. Alexopoulos GS, Abrams RC, Young RC, Shamoian CA. Cornell Scale for Depression in Dementia. Biol Psychiatry 1988;23:271-284.

50. Sunderland T, Alterman IS, Yount D, et al. A new scale for the assessment of depressed mood in demented patients. Am J Psychiatry 1988;145:955-959.

51. Koss E, Weiner M, Ernesto C, et al. Assessing patterns of agitation in Alzheimer's disease patients with the CohenMansfield Agitation Inventory. The Alzheimer's Disease Cooperative Study. Alzheimer Dis Assoc Disord 1997;11 Suppl 2: S45-S50.

52. Camozzato A, Kochhann R, Simeoni C, et al. Reliability of the Brazilian Portuguese version of the Neuropsychiatric Inventory (NPI) for patients with Alzheimer's disease and their caregivers. Int Psychogeriatr 2008;20:383-393.

53. Lima DA, Lourenço RA. [Cross-cultural adaptation of section A of the Cambridge Examination for Mental Disorders of the Elderly-Revised Version (CAMDEX-R) for dementia diagnosis]. Cad Saude Publica 2010;26:1345-1354.

54. Carthery-Goulart MT, Areza-Fegyveres R, Schultz RR, et al. [Brazilian version of the Cornell depression scale in dementia]. Arq Neuropsiquiatr 2007;65:912-915.

55. Chaves ML, Izquierdo I. Differential diagnosis between dementia and depression: a study of efficiency increment. Acta Neurol Scand 1992;85:378-382.

56. Bertolucci PH, Brucki SM, Campacci SR, Juliano Y. [The Mini-Mental State Examination in a general population: impact of educational status]. Arq Neuropsiquiatr 1994; 52:1-7.

57. Almeida OP. Mini mental state examination and the diagnosis of dementia in Brazil. Arq Neuropsiquiatr 1998;56: 605-612.

58. Caramelli P, Herrera E Jr, Nitrini R. O Mini-Exame do Estado Mental no diagnóstico de demência em idosos analfabetos. Arq Neuropsiquiatr 1999;57 Supl 1:S7

59. Bertolucci PH, Okamoto IH, Brucki SM, Siviero MO, Toniolo Neto J, Ramos LR. Applicability of the CERAD neuropsychological battery to Brazilian elderly. Arq Neuropsiquiatr 2001;59:532-536.

60. Brucki SM, Nitrini R, Caramelli P, Bertolucci PH, Ivan H. Okamoto IH. Sugestões para o Uso do Mini-Exame do Estado Mental no Brasil. [Suggestions for utilization of the mini -mental state examination in Brazil]. Arq Neuropsiquiatr 2003;61:777-781.

61. Laks J, Batista EM, Guilherme ER, et al. Mini-mental state examination in community-dwelling elderly: preliminary data from Santo Antonio de Padua, Rio de Janeiro, Brazil. Arq Neuropsiquiatr 2003;61:782-785.

62. Lourenço RA, Veras RP. Mini-Mental State Examination: psychometric characteristics in elderly outpatients. Rev Saude Publica 2006;40:712-719.

63. Laks J, Baptista EMR, Contino ALB, Paula EO, Engelhardt E. Mini-Mental State Examination norms in a communitydwelling sample of elderly with low schooling in Brazil / Normas do Mini-Exame do Estado Mental para uma amostra de idosos com baixa escolaridade residentes na comunidade no Brasil. Cad Saude Publica 2007;23:315-319.

64. Castro-Costa E, Fuzikawa C, Uchoa E, Firmo JOA, LimaCosta MF. Norms for the Mini-Mental State Examination: Adjustment of the cut-off point in population-based studies (evidences from the Bambuí health aging study). Arq Neuropsiquiatr 2008;66:524-528.

65. Lourenço RA, Veras RP, Ribeiro PCC. Confiabilidade testereteste do Mini-Exame do Estado Mental em uma população idosa assistida em uma unidade ambulatorial de saúde. Rev Bras Geriatr Gerontol 2008;11:7-16.

66. Kochhann R, Varela JS, Lisboa CS, Chaves MLF. The Mini Mental State Examination: eeview of cutoff points adjusted for schooling in a large Southern Brazilian sample. Dement Neuropsychol 2010;4:35-41.

67. Teng EL, Hasegawa K, Homma A, et al. The Cognitive Abilities Screening Instrument (CASI): a practical test for crosscultural epidemiological studies of dementia. Int Psychogeriatr 1994;6:45-58.

68. Damasceno A, Delicio AM, Mazo DF, et al. Validation of the Brazilian version of mini-test CASI-S. Arq Neuropsiquiatr 2005;63:416-421.

69. Mioshi E, Dawson K, Mitchell J, Arnold R, Hodges JR. The Addenbrooke's Cognitive Examination Revised (ACE-R): a brief cognitive test battery for dementia screening. Int J Geriatr Psychiatry 2006;21:1078-1085.

70. Nitrini R, Caramelli P, Porto CS, et al. Brief cognitive battery in the diagnosis of mild Alzheimer's disease in subjects 
with medium and high levels of education. Dement Neuropsychol 2007;1:32-36.

71. Takada LT, Caramelli P, Fichman HC, et al. Comparison between two tests of delayed recall for the diagnosis of dementia. Arq Neuropsiquiatr 2006;64:35-40.

72. Carvalho VA, Caramelli P. Brazilian adaptation of the Addenbrooke's Cognitive Examination-Revised (ACE-R). Dement Neuropsychol 2007;1:212-216.

73. Carvalho VA, Barbosa MT, Caramelli P. Brazilian version of the Addenbrooke Cognitive Examination-revised in the diagnosis of mild Alzheimer disease. Cogn Behav Neurol 2010;23:8-13.

74. Rosen WG, Mohs RC, Davis KL. ADAS-COG - A new rating scale for Alzheimer's disease. Am J Psychiatry 1984;141: 1356-1364.

75. Vitaliano PP, Breen AR, Russo J, Albert M, Vitiello MV, Prinz PN. The clinnical utility of the dementia rating scale for assessing Alzheimer patients. J Chronic Dis 1984;37:743-753.

76. Schultz RR, Siviero MO, Bertolucci PH. The cognitive subscale of the "Alzheimer's Disease Assessment Scale" in a Brazilian sample. Braz J Med Biol Res 2001;34:1295-1302.

77. Porto CS, Fichman HC, Caramelli P, Bahia VS, Nitrini R. Brazilian Version of the Mattis Dementia Rating Scale. Diagnosis of mild dementia in Alzheimer.s Disease. Arq Neuropsiquiatr 2003;61:339-345.

78. Malloy-Diniz LF, Cruz MF, Torres VM, Cosenza RM. O teste de aprendizagem auditivo-verbal de Rey: normas para uma populaçäo brasileira. Rev Bras Neurol 2000;36:79-83.

79. Malloy-Diniz LF, Lasmar VA, Gazinelli Lde S, Fuentes D, Salgado JV. The Rey Auditory-Verbal Learning Test: applicability for the Brazilian elderly population. Rev Bras Psiquiatr 2007;29:324-329.

80. Martins SP, Damasceno BP. Prospective and retrospective memory in mild Alzheimer's disease. Arq Neuropsiquiatr 2008;66:318-322.

81. Teruya LC, Ortiz KZ, Minett TS. Performance of normal adults on Rey Auditory Learning Test: a pilot study. Arq Neuropsiquiatr 2009;67:224-228.

82. Magalhães, SS and Hamdan, AC. The Rey Auditory Verbal Learning Test: normative data for the Brazilian population and analysis of the influence of demographic variables. Psychol Neurosci 2010;3:85-91 (Online).

83. Fichman HC, Dias LBT, Fernandes CS, Lourenço R, Caramelli P, Nitrini R. Normative data and construct validity of the Rey Auditory Verbal Learning Test in a Brazilian elderly population. Psychol Neurosci 2010;3:79-84.

84. Bertolucci PHF, Okamoto IH, Toniolo Neto J, Ramos LR, Brucki SMD. Desempenho da população brasileira na bateria neuropsicológica do Consortium to Establish a Registry for Alzheimer's Disease (CERAD). Rev Psiquiatr Clin 1998;25:80-83.

85. Ribeiro PCC, Oliveira BHD, Cupertino APFB, Neri AL, Yassuda MS. Desempenho de idosos na bateria cognitiva CERAD: relações com variáveis sociodemográficas e saúde percebida. Psicol Reflex Crit 2010;23:102-109.

86. Nitrini R, Lefèvre BH, Mathias SC, et al. Testes neuropsico- lógicos de aplicação simples para o diagnóstico de demência. Arq Neuropsiquiatr 1994;52:457-465.

87. Nitrini R, Caramelli P, Herrera Júnior E, et al. Performance of illiterate and literate nondemented elderly subjects in two tests of long-term memory. J Int Neuropsychol Soc 2004; 10:634-638.

88. Vitiello APP, Ciríaco JGM, Takahashi DY, Nitrini R, Caramelli P. Avaliação cognitiva breve de pacientes atendidos em ambulatórios de neurologia geral. Arq Neuropsiquiatr 2007;65:299-303.

89. Nitrini R, Caramelli P, Porto CS, et al. Brief cognitive battery in the diagnosis of mild Alzheimer's disease in subjects with medium and high levels of education. Dement Neuropsychol 2007;1:32-36.

90. Nitrini R, Brucki SMD, Smid J, et al. Influence of age, gender and educational level on performance in the Brief Cognitive Battery-Edu. Dement Neuropsychol 2008;2:114-118.

91. Foss MP, Formigheri P, Speciali JG. Heterogeneity of cognitive aging in Brazilian normal elderls. Dement Neuropsychol 2009;3:344-351.

92. Foss MP, Bastos-Formigheri MS, Speciali JG. Figuras complexas de Rey para idosos. Aval Psicol 2010;9:53-61.

93. Yassuda MS, Flaks MK, Viola LF, et al. Psychometric characteristics of the Rivermead Behavioural Memory Test (RBMT) as an early detection instrument for dementia and mild cognitive impairment in Brazil. Int Psychogeriatr 2010;22:1003-1011.

94. Yassuda MS, Diniz BS, Flaks MK, et al. Neuropsychological profile of Brazilian older adults with heterogeneous educational backgrounds. Arch Clin Neuropsychol 2009;24: 71-79.

95. Flaks MK, Yassuda MS, Regina AC, et al. The Short Cognitive Performance Test (SKT): a preliminary study of its psychometric properties in Brazil. Int Psychogeriatr 2006; 18:121-133.

96. Flaks MK, Forlenza OV, Pereira FS, Viola LF, Yassuda MS. Short cognitive performance test: diagnostic accuracy and education bias in older Brazilian adults. Arch Clin Neuropsychol 2009;24:301-306.

97. Avila R, Moscoso MA, Ribeiz S, Arrais J, Jaluul O, Bottino CM. Influence of education and depressive symptoms on cognitive function in the elderly. Int Psychogeriatr 2009; 21:560-567.

98. Nascimento E (Tese 2000). Adaptação e validação do teste wais-III para um contexto brasileiro.

99. Nascimento E, Figueiredo VLM. WISC-III e WAIS-III: alterações nas versões originais americanas decorrentes das adaptações para uso no Brasil. Psicol Reflex Crit 2002; 15:603-612.

100. Hamdan AC, Bueno OFA. Relações entre controle executivo e memória episódica verbal no comprometimento cognitivo leve e na demência tipo Alzheimer. Estud Psicol (Natal) 2005; 10:63-71.

101. Hamdan AC, Hamdan EMLR. Effects of age and education level on the Trail Making Test in a healthy Brazilian sample. Psychol Neurosci. Online) 2009;2:199-203. 
102. Okamoto IH (Tese 2001). Aspectos cocnitivos da doença de Alzheimer no teste do relógio: avaliaçäo de amostra da populaçäo brasileira/ Cognitive aspects of Alzheimer's disease in clock test: assessment in a Brazilian sample.

103. Fuzikawa C, Lima-Costa MF, Uchoa E, Barreto SM, Shulman K; Bambuí Health and Ageing Study. A population based study on the intra and inter-rater reliability of the clock drawing test in Brazil: the Bambuí Health and Ageing Study. Int J Geriatr Psychiatry 2003;18:450-456.

104. Fuzikawa C, Lima-Costa MF, Uchôa E, Shulman K. Correlation and agreement between the Mini-mental State Examination and the Clock Drawing Test in older adults with low levels of schooling: the Bambuí Health Aging Study (BHAS). Int Psychogeriatr 2007;19:657-667.

105. Atalaia-Silva KC, Lourenço RA. Tradução, adaptação e validação de construto do Teste do Relógio aplicado entre idosos no Brasil. Rev Saude Publica 2008;42:930-937.

106. Aprahamian I, Martinelli JE, Yassuda MS. Doença de Alzheimer em idosos com baixa escolaridade: o teste do Desenho do Relógio pode ser útil no rastreio cognitivo? Rev Soc Bras Clin Med 2008;6:130-134.

107. Lourenço RA, Ribeiro-Filho ST, Moreira Ide F, Paradela EM, Miranda AS. The Clock Drawing Test: performance among elderly with low educational level. Rev Bras Psiquiatr 2008;30:309-315.

108. Aprahamian I, Martinelli JE, Neri AL, Yassuda MS. The accuracy of the Clock Drawing Test compared to that of standard screening tests for Alzheimer's disease: results from a study of Brazilian elderly with heterogeneous educational backgrounds. Int Psychogeriatr 2010;22:64-71.

109. Figueirêdo do Vale PH, Spíndola L, Oliveira MO, Armentano CGC, Porto CS, Brucki SMD. Comparison of performance in neuropsychological tests in amnestic Mild Cognitive Impairment and Alzheimer's disease patients. Dement Neuropsychol 2009;3:41-48.

110. Wagner GP, Trentini CM. Asssessing executive functions in older adults: a comparison between the manual and the computer-based versions of the Wisconsin Card Sorting Test. Psychol Neurosci 2009;2:195-198.

111. Steiner VAG, Mansur LL, Brucki SMD, Nitrini R. Phonemic verbal fluency and age: a preliminary study. Dement Neuropsychol 2008;2:328-332.

112. Machado TM, Fichman HC, Santos EL, Carvalho VA, Fialho PP, Koenig AM, Fernandes CS, Lourenço RA, Paradela EMP, Caramelli P. Normative data for healthy elderly on the phonemic verbal fluency task - FAS. Dement Neuropsychol 2009;3:55-60.

113. Brucki SM, Rocha MS. Category fluency test: effects of age, gender and education on total scores, clustering and switching in Brazilian Portuguese-speaking subjects. Braz J Med Biol Res 2004;37:1771-1777.

114. Caramelli P, Carthery-Goulart MT, Porto CS, CharchatFichman H, Nitrini R. Category fluency as a screening test for Alzheimer disease in illiterate and literate patients. Alzheimer Dis Assoc Disord 2007;21:65-67.

115. Argimon IIL, Stein LM. Habilidades cognitivas em indivídu- os muito idosos: um estudo longitudinal. Cad Saude Publica 2005;21:64-72.

116. Radanovic M, Diniz BS, Mirandez RM, et al. Verbal fluency in the detection of mild cognitive impairment and Alzheimer's disease among Brazilian Portuguese speakers: the influence of education. Int Psychogeriatr 2009;21:1081-1087.

117. Matioli MN, Caramelli P. Limitations in differentiating vascular dementia from Alzheimer's disease with brief cognitive tests. Arq Neuropsiquiatr 2010;68:185-188.

118. Pereira FS, Yassuda MS, Oliveira AM, Forlenza OV. Executive dysfunction correlates with impaired functional status in older adults with varying degrees of cognitive impairment. Int Psychogeriatr 2008;20:1104-1115.

119. Canali F, Brucki SM, Bueno OFA. Behavioural assessment of the dysexecutive syndrome (BADS) in healthy elders and Alzheimer's disease patients: preliminary study. Dement Neuropsychol 2007;1:154-160.

120. Armentano CGC, Porto CS, Brucki SMD, Nitrini R. Study on the performance of Behavioural Assessment of the Dysexecutive Syndrome (BADS) in healthy individuals, Mild Cognitive Impairment and Alzheimer's disease: preliminary study. Dement Neuropsychol 2009;3:101-107.

121. Beato RG, Nitrini R, Formigoni AP, Caramelli P. Brazilian version of the frontal assessment Battery (FAB): preliminary data on administration to healthy elderly. Dement Neuropsychol 2007;1:59-65.

122. Kaplan EF, Goodglass H, Weintraub S. Boston Naming Test. 2nd ed. Philadelphia: Lippincott Williams\&Wilkins; 2001.

123. Miotto EC, Sato J, Lucia MC, Camargo CH, Scaff M. Development of an adapted version of the Boston Naming Test for Portuguese speakers. Rev Bras Psiquiatr 2010;32: 279-282.

124. Novaretti TMS, Freitas MIDA, Mansur LL, Nitrini R, Radanovic M. Comparison of language impairment in lateronset depression and Alzheimer's disease. Acta Neuropsychiatrica 2011;3:62-68.

125. Radanovic M, Mansur LL, Scaff M. Normative data for the Brazilian population in the Boston Diagnostic Aphasia Examination: influence of schooling. Braz J Med Biol Res 2004; 37:1731-1738.

126. Soares EC, Ortiz KZ. Influence of schooling on language abilities of adults without linguistic disorders. Sao Paulo Med J 2009;127:134-139.

127. Hughes CP, Berg L, Danziger WL, Coben LA, Martin RL. A new clinical scale for the staging of dementia. Br J Psychiatry 1982;140:566-72.

128. Montaño MB, Ramos LR. Validity of the Portuguese version of Clinical Dementia Rating. Rev Saude Publica 2005; 39:912-917.

129. Maia AL, Godinho C, Ferreira ED, et al. Application of the Brazilian version of the CDR scale in samples of dementia patients. Arq Neuropsiquiatr 2006;64:485-489.

130. Chaves ML, Camozzato AL, Godinho C, et al. Validity of the clinical dementia rating scale for the detection and staging of dementia in Brazilian patients. Alzheimer Dis Assoc Disord 2007;21:210-217. 


\section{GROUP RECOMMENDATIONS IN ALZHEIMER'S DISEASE AND VASCULAR DEMENTIA OF THE BRAZILIAN ACADEMY OF NEUROLOGY}

Amauri B. da Silva [UNINEURO, Recife (PE)]; Ana Cláudia Ferraz [Serviço de Neurologia do Hospital Santa Marcelina (SP)]; Analuiza Camozzato de Pádua [Universidade Federal de Ciências da Saúde de Porto Alegre (UFCSPA); Hospital de Clínicas de Porto Alegre (UFRGS) (RS)]; Antonio Lúcio Teixeira [Departamento de Clínica Médica, Faculdade de Medicina da Universidade Federal de Minas Gerais, Belo Horizonte (MG)]; Ayrton Roberto Massaro [Instituto de Reabilitação Lucy Montoro (SP)]; Benito Pereira Damasceno [Departamento de Neurologia da Universidade Estadual de Campinas (SP)]; Carla Tocquer [Universidade Federal do Rio de Janeiro (RJ)]; Carlos Alberto Buchpiguel [Departamento de Radiologia, Faculdade de Medicina da Universidade de São Paulo (SP)]; Cássio Machado C. Bottino [Programa Terceira Idade, Instituto de Psiquiatria do Hospital das Clínicas da Faculdade de Medicina da Universidade de São Paulo (FMUSP) (SP)]; Charles André [Faculdade de Medicina UFRJ; SINAPSE Reabilitação e Neurofisiologia (RJ)]; Delson José da Silva [Núcleo de Neurociências do Hospital das Clínicas da Universidade Federal de Goiás (UFG); Instituto Integrado de Neurociências (IINEURO), Goiânia (GO)]; Denise Madeira Moreira [Departamento de Radiologia Faculdade de Medicina - UFRJ; Setor de Radiologia - INDC - UFRJ (RJ)]; Eliasz Engelhardt [Setor de Neurologia Cognitiva e do Comportamento - INDC - CDA/IPUB - UFRJ (RJ)]; Elza Dias-Tosta [Presidente da Academia Brasileira de Neurologia, Hospital de Base do Distrito Federal (DF)]; Emílio Herrera Junior [Departamento de Medicina Interna, Faculdade de Medicina de Catanduva (SP)]; Francisco de Assis Carvalho do Vale [Universidade Federal de São Carlos (UFSCar), Departamento de Medicina (DMed) (SP)]; Gabriel R. de Freitas [Instituto D'or de Pesquisa e Ensino; Universidade Federal Fluminense (RJ)]; Hae Won Lee [Instituto de Radiologia, Hospital das Clínicas da Faculdade de Medicina da Universidade de São Paulo e Hospital Śrio-Libanês (SP)]; Ivan Hideyo Okamoto [Departamento de Neurologia e Neurocirurgia; Instituto da Memória - Universidade Federal de São Paulo - UNIFESP (SP)]; Jerusa Smid [Grupo de Neurologia Cognitiva e do Comportamento do Hospital das Clínicas da Faculdade de Medicina da Universidade de São Paulo (FMUSP) (SP)]; João Carlos Barbosa Machado [Aurus IEPE - Instituto de Ensino e Pesquisa do Envelhecimento de Belo Horizonte; Faculdade de Ciências Médicas de Minas Gerais (FCMMG), Serviço de Medicina Geriátrica do Hospital Mater Dei (MG)]; José Antonio Livramento [Laboratório de Investigação Médica (LIM) 15, Faculdade de Medicina da Universidade de São Paulo (SP)]; José Luiz de Sá Cavalcanti [Departamento de Neurologia - INDC - UFRJ; Setor de Neurologia Cognitiva e do Comportamento - INDC - UFRJ (RJ)]; Liana Lisboa
Fernandez [Departamento de Ciências Básicas da Saúde, Fundação Universidade Federal de Ciências da Saúde de Porto Alegre (RS)]; Márcia Radanovic [Laboratório de Neurociências - LIM27, Departamento e Instituto de Psiquiatria da Faculdade de Medicina da Universidade de São Paulo (FMUSP) (SP)]; Márcio Luiz Figueredo Balthazar [Universidade Estadual de Campinas (UNICAMP), Faculdade de Ciências Médicas (FCM), Departamento de Neurologia (SP)]; Nasser Allam [Universidade de Brasília (UnB), Laboratório de Neurociências e Comportamento, Brasília (DF)]; Norberto Anízio Ferreira Frota [Universidade de Fortaleza (UNIFOR), Serviço de Neurologia do Hospital Geral de Fortaleza (HGF) (CE)]; Orestes Forlenza [Laboratório de Neurociências - LIM27, Departamento e Instituto de Psiquiatria da Faculdade de Medicina da Universidade de São Paulo (FMUSP) (SP)]; Paulo Caramelli [Departamento de Clínica Médica, Faculdade de Medicina da Universidade Federal de Minas Gerais, Belo Horizonte (MG)]; Paulo Henrique Ferreira Bertolucci [Universidade Federal de São Paulo (UNIFESP), Setor de Neurologia do Comportamento - Escola Paulista de Medicina, São Paulo (SP)]; Regina Miksian Magaldi [Serviço de Geriatria do Hospital das Clínicas da FMUSP, Centro de Referência em Distúrbios Cognitivos (CEREDIC) da FMUSP (SP)]; Renata ArezaFegyveres [Grupo de Neurologia Cognitiva e do Comportamento do Hospital das Clínicas da Faculdade de Medicina da Universidade de São Paulo (FMUSP) (SP)]; Renato Anghinah [Grupo de Neurologia Cognitiva e do Comportamento do Hospital das Clínicas da Faculdade de Medicina da Universidade de São Paulo (FMUSP); Centro de Referência em Distúrbios Cognitivos (CEREDIC) da FMUSP (SP)]; Ricardo Nitrini [Grupo de Neurologia Cognitiva e do Comportamento do Hospital das Clínicas da Faculdade de Medicina da Universidade de São Paulo (FMUSP); Centro de Referência em Distúrbios Cognitivos (CEREDIC) da FMUSP (SP)]; Rodrigo Rizek Schultz [Setor de Neurologia do Comportamento do Departamento de Neurologia e Neurocirurgia da Universidade Federal de São Paulo, Núcleo de Envelhecimento Cerebral (NUDEC) - Instituto da Memória (UNIFESP) (SP)]; Sonia Maria Dozzi Brucki [Grupo de Neurologia Cognitiva e do Comportamento da Faculdade de Medicina da Universidade de São Paulo; Centro de Referência em Distúrbios Cognitivos (CEREDIC) da FMUSP; Hospital Santa Marcelina (SP)]; Tânia Novaretti [Faculdade de Filosofia e Ciências, Campus de Marília, da Universidade Estadual Paulista (UNESP) (SP)]; Valéria Santoro Bahia [Grupo de Neurologia Cognitiva e do Comportamento do Hospital das Clínicas da Faculdade de Medicina da Universidade de São Paulo (FMUSP) (SP)]; Ylmar Corrêa Neto [Universidade Federal de Santa Catarina (UFSC), Departamento de Clínica Médica, Florianópolis (SC)]. 